\title{
The Metaphysics of Justice: Ayelala's Rise in Benin and Other Parts of Edo State
}

\author{
Benson Ohihon Igboin \\ Adekunle Ajasin University Akungba-Akoko, Nigeria \\ bensonigboin@gmail.com
}

\begin{abstract}
This article discusses the origin, spread and efficacy of the deity Ayelala, who is responsible for the execution of justice. After an account of the deification of Ayelala, it discusses the recent spread of the deity, originally from the areas inhabited by the ljaw, Ilaje, and Ikale, to Benin, where her presence has been highly effective in combating public crimes such as theft, robbery and kidnapping. Beyond the punishment and control of public crimes, a report of Ayelala's revelations about the causes of a personal death also illustrates the deity's ability to provide justice in personal matters. The article argues that doubts about Ayelala's existence, as put forward by some critics, are illogical and indeed irrelevant as long as the deity is seen to produce results. Building on the arguments of the British anthropologist E. E. Evans-Pritchard, who suggests that witchcraft explains unfortunate events, this article argues that the experience of certain fortunate events, such as the punishment of evildoers or the revelation of metaphysical causes of death, confirm the existence of Ayelala as a counter-force to witchcraft and other forms of metaphysical evil.
\end{abstract}

\section{Ayelala as a Goddess or Deity of Justice}

The origin of Ayelala and her relationship to justice is critical to the overall argument of how people appreciate her efficacy even in contemporary society. Awolalu says that Ayelala could be traced to an Ilaje man who, after committing 
adultery, fled to Ijaw territory for asylum. ${ }^{1}$ Ojo actually mentions that the adulterous act was committed by "one Tenetan (a commoner) with the wife of Keko (a high chief)".2 Traditionally, the adulterer was to be put to death. Thus when the Ilaje people heard that the adulterous man was under the protection of the Ijaw, a feud broke out between the two communities. It took some well-meaning members of both communities to broker peace; agreeing that though the adulterous man would no longer be executed, a scapegoat was needed to appease the Ilaje. A slave woman became the scapegoat; she is known today as Ayelala.

From the account of Ojo, we can guess that Tenetan went into self-exile because of his status in the community. As usual in many traditional communities, a titled person enjoys great privileges which are also extended to his family. Even though we do not know why Keko's wife would condescend so low as to commit adultery with a commoner, it is clear from the hunt for Tenetan and the feud that resulted from it with the Ijaw that Keko was a highly influential individual in the Ilaje community. It can also be surmised that the hunt for Tenetan was meant to appease the gods of Ilajeland but also to restore the social prestige of Keko. In indigenous African religious space, propitiation does not only appease the anger of the gods, but also restores peace and harmony among the members of the community. The act of reconciliation brings about healing and strengthens the vital force of the community. ${ }^{3}$ The hunt for Tenetan can be suggested to serve the cause of justice because it is just natural that a person who commits such a heinous offence against his fellow should be punished. That Tenetan was not put to death as the then existing law demanded and a scapegoat was used instead suggests that human beings can also negotiate with the gods. According to Adeleke, the gods may sometimes behave like humans, and may thus accept a substitute. ${ }^{4}$ But what is important in the

1. J. Omosade Awolalu, Yoruba Beliefs and Sacrificial Rites (London: Longman, 1979), 41-44.

2. Matthias Olufemi Dada Ojo, "Incorporation of Ayelala Traditional Religion into Nigerian Criminal Justice System: An Opinion Survey of Igbesa Community People in Ogun State, Nigeria," Issues in Ethnology and Anthropology, 9.4 (2014): 1026. There is an lesson about the appreciation of family members in this account, as only the names of men are mentioned. One would have thought that since Tenetan was named publicly, the adulteress, ought to have been named as well. We suggest that her name was kept quiet to protect her (and perhaps her children).

3. Laurenti Magasa, African Religion: The Moral Traditions of Abundant Life (Nairobi: Paulines 1997); Benezet Bujo, The Ethical Dimension of Community: The African Model and the Dialogue between North and South (Nairobi: Paulines Publications Africa, 1997); Ferdinand C. Ezekwonna, African Communitarian Ethic: The Basis for the Moral Conscience and Autonomy of the Individual - Igbo Culture as a Case Study, (Bern: Peter Lang, 2005).

4. Durotoye A. Adeleke, "Even the Gods are Fools," ORITA: Ibadan Journal of Religious Studies, xxxvii (June \& December, 2005): 11-31. 
case of the gods in this account is the fact that "blood", which was required, was given.

We can also interrogate why a slave woman should be the victim of an offence committed by a man. Would it not have been more appropriate for a male victim to be sacrificed? No information is provided that might help us to form an opinion on why there was such a twist. Familusi argues that it is a credit to womanhood that the deity is a woman, ${ }^{5}$ but this does not answer our question. According to Kuponu, slavery existed prior to the Atlantic slave trade not only among the people of the Yoruba coast but also in the hinterland. He informs us that kings and warriors raided vulnerable settlements and carted away able-bodied men and women who served them in different capacities. Among the uses of slaves was the practice of burying some of them with a king, meaning that slaves could be killed for spiritual reasons. It is likely that Ayelala's substitution for the freeborn offender took place as the result of this practice.

Ayelala, which is now the name of a deity, was actually an exclamation made by the slave woman when she was about to be sacrificed. Literally, Ayelala was an imprecatory utterance at the point of her being sacrificed, which when interpreted means "the world is not only great but also incomprehensible." In a more appropriate sense, it means: "the world is terrible". ${ }^{6}$ She could have wondered why she was the scapegoat for an offence she did not commit. For her, it must have seemed unjust that an innocent person had to take the place of a guilty person on the altar of sacrifice. The paradox in the narrative, as will be shown below, is the fact that even though Ayelala was not happy as the victim and could have been angry about the injustice to her personality, she became the deity of justice. In a natural way, one would think that if Tenetan was the one who had died for his sin, justice would have been served better. But only the paradox of sacrificing an innocent woman for the crime of a man enabled Ayelala to become the deity of justice.

Before she was sacrificed, the Ilaje and the Ijaw had to make some charter of covenant agreeing that they would not plan or execute evil against members of the two communities; and that stealing, sorcery, witchcraft among others must be shunned whereas faithfulness and honesty must be adopted. They agreed that any breach of any of the covenant would be visited with the agony that Ayelala experienced. These terms of covenant were witnessed by Ayelala, who at the point of her death vowed to punish non-compliance. It was this

5. O. O. Familusi, "African Culture and the Status of Women: The Yoruba Example," The Journal of Pan African Studies, 5.1 (2012): 299-312.

6. J. Omosade Awolalu, Yoruba Beliefs and Sacrificial Rites (UK: Longman, 1979), 4144. 
belief in justice that led to her apotheosis, especially after the communities experienced several mysterious deaths consequent upon their breach of the terms of covenant. The communities had to re-enact the covenant as they came to the realization that it was sealed with Ayelala's blood ab initio. ${ }^{7}$

\section{Philosophical Arguments on the Efficacy of Ayelala}

Ayelala is not limited by time and space in carrying out her role of adjudication and justice. It is widely believed that even if a culprit is overseas, once invoked Ayelala will surely bring him or her to justice. In addition, it is also held that she dispenses justice as quickly as possible. In her cult, people believe that justice cannot be delayed, let alone denied. Thus people who are pressed for quick justice approach her, both at home and abroad. As stated by Sheloya:

Authorities in the diaspora fear the word getting out because Ayelala does not discriminate between public and secret crimes against Africans who honor the Ancestors and Orishas regardless of their traditional or professed religions, nor does she show any mercy. She also does not stop at the 'trigger man', and punishes all who aided and abetted the wrongdoer.... She is so effective that many times, when someone suspects that Ayelala has been called about them, they go to a shrine and confess and offer to make amends and restitution voluntarily. ${ }^{8}$

However, others argue that the operations ascribed to Ayelala are caused purely by unfounded belief and by the unhygienic lifestyle of the people among whom the deity plays a powerful role. Critics of the belief in Ayelala maintain that her suspects and victims are merely hypnotized after being "intimidated and injected with lethal chemicals which not only made them to begin to confess but would also make their stomachs and legs swollen." ${ }^{\text {"W }}$ Wile hygiene and lethal chemicals may or may not be a problem, the question remains why Ayelala would punish only those who have committed crimes: surely if the effects of such practices affected people randomly, no one would fear a deity like Ayelala.

In his discussion of witchcraft among the Azande, Evans-Pritchard argued that unfortunate events are convincingly explained by witchcraft, which is un-

7. Awolalu, 44.

8. Sheloya, "Protection from Authorities and Police", http://zindoki.com/Chtok, accessed 28th October, 2016.

9. See "Ayelala is Fake" Ikale News, 21 October 2015, http:///www.ikalenews.com/ news//26-ayelala-is-fake, accessed 28th October, 2016. 
derstood as the metaphysical reason behind the natural causes that contribute to such an event. ${ }^{10}$ In a similar vein, this article argues that the experience of certain fortunate events, such as the punishment of evildoers or the revelation of metaphysical causes of death, can be taken as a demonstration of proof for the existence and efficacy of Ayelala, which is a metaphysical counter-force to evils such as witchcraft as well as crime. When justice is dispensed after an appeal to Ayelala, it is "rational" to believe in her powers.

The non-rational stance of many of Ayelala's critics is further revealed in statements that acknowledge the existence of other metaphysical powers, such as witchcraft:

It may be true that many of them [victims of Ayelala] were actually witches and might have committed atrocities. But I don't think it was Ayelala that caught them or made them to confess. Out of fear, they confessed and nobody would drink those concoctions and would not have kidney failure and consequently all those symptoms. ${ }^{11}$

The point at issue here is that the author seems to believe that witches, a metaphysical force for evil, exist, but that a metaphysical counter-force like Ayelala does not exist. As it would have been reasonable to either accept or reject both instead of accepting one and rejecting the other, this argument must be criticized for its non-rational approach. The position fails its own test. Now we briefly turn to some exhibits of the efficacy of Ayelala.

\section{The rise of Ayelala in Edo State and beyond}

The quest and search for justice are part of human nature and community life. People are capable of many things to have justice done, or to find solutions to the mysterious problems of life. This motivation explains how Ayelala spread from the Ilaje, Ijaw and Ikale areas that are considered her home towards the east. According to Ehianu, it is difficult to ascertain exactly when Ayelala shrines first appeared in Edo State, because the relationship between the Bini and Yoruba is a long standing one which was and has continued to be lubricated by trade, politics, historical and socio-cultural factors. For that reason it may be misleading to suggest that Ayelala has spread to Benin only recently. It is certainly possible that she was worshipped there in the past, and that her worship is now being revived.

10. E. E. Evans-Pritchard, Witchcraft, Oracles and Magic Among the Azande (Oxford: Oxford University Press, 1937), 63-83.

11. See "Ayelala is Fake" Ikale News, 21 October 2015, http://www.ikalenews.com/ news//26-ayelala-is-fake, accessed 28th October, 2016. 
But while there are "several independent Ayelala temples in Benin, each claiming greater historicity, originality and efficiency,"12 the Ayelala shrine at Iguosa near Benin City, today one of the most important Ayelala shrines in Edo land, is a modern establishment. Ayelala's Chief Priest in Benin, Godspower Ojoduma, was a member of Jehovah's Witnesses before he began to worship Ayelala in 1981. He converted to the worship of Ayelala as a result of personal difficulties. After approaching Matthew Abadun in Irele, Ondo State, who preached to him and assured him of the efficacy of Ayelala, Odojuma willingly converted. For the initiation, one is required to make a declaration of faith in Ayelala. Thereafter, one would bring six yards of white cloth, a cock, one lump of native chalk, four bottles of gin, kola nuts, five cowries and nine shillings, which are then shared equally among the Ilaje and Ijaw priests. ${ }^{13}$ It was only after his initiation that Ojoduma built the current Ayelala temple in Iguosa. ${ }^{14}$

The rise of Ayelala in Edo State can be traced to an incident of 2005, when a fire razed Oba Market in Ring Road, Benin City. Many shops were burned and looted. But many shops that were not torched by fire were also looted by thieves. It was the latter that immediately provoked the anger of the Bini people. After several failed efforts by the Police to apprehend any of the looters, Chief John Osamede Adun invited the Chief Priest of Ayelala, who on arrival gave a 24-hour ultimatum to the unidentified looters to return the stolen goods or faced the wrath of Ayelala thereafter. Fearful of the deity's swift justice, the thieves returned all the stolen goods to the various shops from where they had stolen them. ${ }^{15}$

When a few months later Uselu Market, also in Benin City, was set ablaze and looters again carted away people's goods, the invocation of Ayelala again ensured that they were all returned. ${ }^{16}$ This effectiveness contributed to the fact that, as Ehianu points out, "Ayelala has become a household name in Benin because the deity is sincere, truthful, and not partial in her dealings." ${ }^{7}$

In 2010, Ayelala was invoked at a public ceremony in which Oba Erediuwa of Benin publicly pronounced a curse on robbers and kidnappers in the at-

12. Wilson Eze Ehianu, "The Resurgence of Aiyelala deity and social justice in Benin: An Indictment of the Church and the Judiciary," in George U. Ukagba, Des O. Obi and Iks J. Nwankwor, eds., The KPIM of Social Order: A Season of Inquiry, Meaning and Significance in the Modern World (Lightning Source UK Ltd, 2013), 484.

13. Ibid., 485.

14. Ibid., 484 .

15. Ibid., 483.

16. Don Akhilomen, "The Resurgence of Ayelala in Benin Kingdom: An Indictment of the Conventional Dispensation of Justice in Nigeria", http://ihuanedo.ning.com/profiles/ blogs/the-resurgence-of-ayelala-in, accessed 28th October, 2016.

17. Ehianu, "The Resurgence of Aiyelala deity and social justice in Benin," 485. 
tempt to curb local crime. Like other parts of southern Nigeria, Benin had experienced a spate of kidnappings of local professionals, such as businessmen and doctors, and public outrage was great. The fact that the Oba was accompanied during this act by Chief Sam Igbe, the Iyase (Prime Minister) of Benin Kingdom, and Chief Nosakhare Isekhure, the Isekhure of Benin Kingdom (Chief Priest of the Kingdom), and applauded by a large crowd, illustrates the strength of local belief in Ayelala. ${ }^{18}$

The eastward spread or re-validation of Ayelala is not limited to Benin City alone. At Oah, in Okpuje, Iuleha, Owan-West Local Government Area, Edo State, an Ayelala shrine has been in existence since 1992. It was brought to Oah by $\mathrm{Mr}$ Aikhelomen Iriemi, who after being initiated in Ondo State established it among his people. Before Mr Iriemi sought out Ayelala and the shrine was built, the community had been faced with many mysterious deaths. Several deaths of young people, both at home and outside the community, gave people concern, and it was considered important to ensure that these deaths were not linked to witchcraft. ${ }^{19}$

Oah community also suffered from the wider social changes, possibly linked to the failed return to democracy in 1993. At the time, robbery activities, which were previously unknown to the community, became prevalent and injustice had become a common experience. The police was seen as corrupt and unable to help the oppressed. Moreover, young people involved in illicit businesses began to use their ill-gotten wealth to oppress innocent people, which also caused social unrest in the community. Iriemi believed that the once peaceful and respectable community was falling apart, and that bringing Ayelala to the community would be a contribution to the restoration of peace and harmony in Oah. ${ }^{20}$ After the death of the pioneer priest, Mr Aikhelomen Iriemi, Mr. Akhidelo took over. Unfortunately, Mr. Akhidelo was ill when the researcher visited him, and not all historical and operational details could be confirmed. Even so, it could be observed that there were many clients who regularly visited the shrine either to invoke or thank Ayelala. Ayelala has also been documented to exist in other communities in Edo State.

In an analysis of Nigeria beyond Edo State, Stephen Ellis confirms that "Ayelala ... is a deity popular all over Western Nigeria, widely considered

18. "Oba of Benin flexes muscle, curses kidnappers, robbers", The Vanguard Newspaper June 12, 2010.

19. An interview with Mr Timothy Ohikhuare, 52 years, a teacher, 3rd October, 2016.

20. Ibid. 
as a truth-telling juju that can be invoked to punish those who offend against popular notions of law and order." ${ }^{21} \mathrm{He}$ argues that

The cult of Ayelala is so popular that it has become an alternative to the official state system of justice. People go far more readily to a shrine of Ayelala than to the police if they have had their houses robbed, and they are far more likely to get their goods back, as Ayelala inspires respect and fear even among criminals. ${ }^{22}$

But while popular belief in the efficacy of Ayelala in helping to fight crime is high, no step has been taken officially to recognize and incorporate it into the legal system in Nigeria. The argument for alternative dispute resolution mechanism has however not been infrequent. Njokede, for instance, argues that the deity Ayelala and her devotees should be brought into the modern judicial system for trial for killing innocent people. However, he does not believe that Ayelala actually kills culprits. Like Ellis, he suggests that devotees of Ayelala are the ones that physically kill culprits, either directly or indirectly (through poison). ${ }^{23}$ Somewhat ironically, Njokede asserts that it is unscientific for a police officer charged with the responsibility of enforcing the law to publicly declare that a policewoman was killed by Ayelala for participating in the looting. ${ }^{24}$

But Njokede ignores the fact that a policewoman charged with the responsibility of protecting the law, who yet joined looters to cart away people's goods, falls precisely into Ayelala's remit. Therefore her death logically confirms not only her existence but also her efficacy to many people. (In fact, even if the death of such a person occurs simply as a 'fortunate' event, that does not prove that Ayelala does not exist.) More generally, it does not seem rational to argue in favor of an inclusion of Ayelala into the justice system if one does not believe in her existence.

\section{The resolution of an unexpected death in Oah}

The researcher himself witnessed the efficacy of Ayelala in Edo communities when he participated in a necromantic session at the Ayelala shrine in Oah

21. Stephen Ellis, This Present Darkness: A History of Nigerian Organized Crime (Oxford: Oxford University Press, 2016), 195.

22. Ibid., 196.

23. Njokede, "Ayelala God Killed Looters of Oba Market-fire in Benin City", http://sahara reporters.com/2010/10/30/ayelala-god-killed-looters-oba-market-fire.benin-city, accessed 28th October, 2016.

24. Ibid. 
before the start of this research, in February 2003. At that time, his cousin, a young policeman, had died, and his sudden demise had raised a lot of suspicions and insinuations. As there was an urgent need to clear the air, several meetings were held by family members as to which of the gods or deities to consult. After long debates, Ayelala at Oah was decided upon, and that afternoon close to a hundred people went to the shrine in sad groups.

After some consultations had taken place between the representatives of the families of the deceased and the priest and elders of Ayelala, the necromantic session began. An uwulo was brought and two young men carried it at both edges: the " $u$ wolo is a metaphysical stick used to detect stolen or lost items and culprits in the community. The stick is covered by white cloth and fresh palm fronds." ${ }^{25}$ Before the uwulo started to operate, the Chief Priest made some incantations and invocations. As these were going on, the bearers of the uwolo were seen staggering as if being moved by some forces beyond their control. This is described as being possessed by the spirit of Ayelala.

The bearers' bodies became supple and flexible, twisting in a frenzied manner. In one swift move, they arrived at the end of the ritual as though their feet were suspended in the air, as if defying the law of gravity. It was revealed that an unidentified member of the family of the deceased had been told to hide something somewhere. When asked who had hidden something, the uwolo rested on a woman who attested to the fact that she had hidden something. In another move, after some search, the uwolo went to the spot, far away from the shrine, in the village where she had dug a hole in the ground and hidden some money. This exercise was revealed later to be a mock exercise to test the efficacy of the deity in her ability to detect and reveal secrets, and it convinced even the sceptics that Ayelala was efficacious.

Thereafter, the spirit of the deceased was invoked to answer the questions posed to it. The deceased was asked if his death had been natural. In response to this, the uwolo did not "drink water," meaning that the death was not natural. The spirit was asked if the young man had been killed by a witch. Uwolo did not drink water, which meant that no witch was responsible for his death. The spirit was then asked if it had been killed by poison. Uwolo did not drink water either. After many questions, the question was asked if the young man had died as a result of swearing or a curse. The uwolo, at this point, went to drink water. Finally it was revealed that the young man had died because his mother had invoked and cursed with a certain deity several years back, when

25. Benson O. Igboin, "Can corruption and dishonesty be eradicated from Nigeria? If so, how? And what role can Adekunle Ajasin University, Akungba-Akoko, play in such undertaking?" An Unpublished Essay competition submitted to the Governing Council of Adekunle Ajasin University, August 2015. The author came second in the competition. 
her prayers were answered by it. However, she had then neglected the deity. And as it is common with many deities, it had the caused havoc in her life to remind her of her ongoing obligations towards the deity.

Even though the result was not immediately accepted by all, all members of the family were psychologically relieved that no human being had had a hand in the young man's death. The psychological satisfaction that the death was not caused by a person pervades till date.

As in the other areas of Ayelala's activity, the necromancy or "metaphysical autopsy" was believed to be more authentic and factual than any medical evidence, such as the autopsy report from the hospital where the young man died. When, at a later time, the researcher asked the immediate family whether they had looked at the autopsy to find out whether there was any problem, such as a genetic disease or disposition that could be forestalled in others, the effort was completely misunderstood, and emotions and tears flowed.

In cases like this, where the deceased was a prosperous young person, it is apparent to all observers that the death must be caused by metaphysical forces and agents, which should be known and appeased if and when demanded. Beyond the prevalence of metaphysical causes of death, the bereaved may suspect some unnamed people, and in some instances, named persons. Necromancy, therefore, is resorted to because of either fear or suspicion, and the revelations of the dead about the reasons for their demise heal better than medical autopsy reports. After all, even a physical cause that can be clearly identified as such may have been caused by a metaphysical cause. Following this logic, Ayelala's facilitation of necromancy enabled the researcher's extended family to ensure that justice was not ignored. ${ }^{26}$

\section{Conclusion}

The article has shown that expansion of Ayelala's influence beyond its home areas among the Ikale, Ilaje and Ijaw to Benin and other parts of Edo State reflects both the failure of the modern state to provide a judicial system and a police force that can guarantee justice at the social level and the need for justice in individual cases, such as unexplained deaths. As the supernatural powers of Ayelala play a critical role in justice delivery among Nigerians, and especially the Yoruba and Edo, the cogent arguments against the existence of metaphysical forces in human affairs are irrelevant, even when they are consis-

26. See also Benson O. Igboin, "Necropsy and Necromancy: A Critical Inquiry into the Cause of Death among the Owan People of Nigeria" in S. O. Oyewole, et. al., eds., Science in the Perspective of African Religion, Islam and Christianity (Ilorin: LSI and NASTRENS, 2010), 69-87. 
tent. Just as the causes of apparently natural deaths or injustices may be metaphysical, so the suffering of the culprits, whether inflicted physically by drugs or violence or not, beings, may be linked to a metaphysical cause.

As this article has demonstrated, given the practical effectiveness of Ayelala, it seems narrow-minded to deny her existence: a deity that has sustained herself in traditional justice delivery for centuries cannot be wiped off by the stroke of epistemic objection. Surely if ever the deity fails to make herself felt, her pragmatic followers will no longer consider her useful, but as long as she appears to be more effective than other forces of justice, Ayelala not only exists but grows in influence. 